\title{
Simulation of the influence of historical land cover changes on the global climate
}

\author{
Y. Wang ${ }^{1,2}$, X. Yan ${ }^{2,3}$, and Z. Wang ${ }^{4}$ \\ ${ }^{1}$ College of Civil Aviation, Nanjing University of Aeronautics and Astronautics, Nanjing 210016, China \\ ${ }^{2}$ Key Laboratory of Regional Climate-Environment for East Asia, Chinese Academy of Sciences, Beijing 10029, China \\ ${ }^{3}$ State Key Laboratory of Earth Surface Processes and Resource Ecology (ESPRE), College of Global Change and Earth \\ System Science, Beijing Normal University, 19 Xinjiekouwai Street, Haidian District, Beijing 100875, China \\ ${ }^{4}$ British Antarctic Survey, Cambridge CB30ET, UK
}

Correspondence to: Y. Wang (wytea@126.com)

Received: 1 August 2012 - Revised: 4 April 2013 - Accepted: 30 April 2013 - Published: 5 June 2013

\begin{abstract}
In order to estimate biogeophysical effects of historical land cover change on climate during last three centuries, a set of experiments with a climate system model of intermediate complexity (MPM-2) is performed. In response to historical deforestation, the model simulates a decrease in annual mean global temperature in the range of $0.07-0.14{ }^{\circ} \mathrm{C}$ based on different grassland albedos. The effect of land cover changes is most pronounced in the middle northern latitudes with maximum cooling reaching approximately $0.6^{\circ} \mathrm{C}$ during northern summer. The cooling reaches $0.57^{\circ} \mathrm{C}$ during northern spring owing to the large effects of land surface albedo. These results suggest that land cover forcing is important for study on historical climate change and that more research is necessary in the assessment of land management options for climate change mitigation.
\end{abstract}

Keywords. Meteorology and atmospheric dynamics (Climatology)

\section{Introduction}

During the last few centuries, humans have significantly changed the land cover surface, the biogeophysical effects of which are the change in the surface roughness, transpiration and albedo. Previous studies of this effect of historical land cover change have revealed a global averaged cooling effect, which is the response to modified surface albedo and radiative forcing through partitioning of available energy between sensible and latent heat (Bonan, 1997, 1999; Chase et al., 2000; Pitman and Zhao, 2000; Govindasamy et al., 2001;
Betts, 2001; Matthews et al., 2004; Feddema et al., 2005; Shi et al., 2007).

Using the National Center for Atmospheric Research (NCAR) climate model CCM1, Bonan et al. (1992) revealed that colder winter and summer temperatures in temperate and high northern latitudes partly resulted from oceanic influence. Chase et al. (2000), using NCAR CCM3 with fixed ocean mode, found a global temperature warming of $0.05^{\circ} \mathrm{C}$ in northern winter. Betts (2001), within numerical experiments using the 3rd Hadley Centre Atmospheric General Circulation Model (HadAM3), revealed a approximately $1-2{ }^{\circ} \mathrm{C}$ cooler in winter and spring over northern mid-latitude agricultural regions in comparison with their previously forested state, due to deforestation increasing the surface albedo by approximately 0.1 during periods of snow cover. Bounoua et al. (2002), in deforestation experiments with a general circulation model (GCM) coupled to a the Simple Biosphere Model ( $\mathrm{SiB} 2$ ), found that conversion of forest and grassland to cropland led to a cooling of $0.7^{\circ} \mathrm{C}$ in summer and $1.1^{\circ} \mathrm{C}$ in winter in temperate latitudes but a warming of $0.8^{\circ} \mathrm{C}$ year round in the tropics and subtropics. Pitman et al. (2009), using seven climate models, showed that five models simulated statistically significant cooling in summer in near-surface temperature over regions of land cover change and one simulated warming. However, while the global cooling effects of historical deforestation could be modeled appropriately, the seasonal response of climate to historical land cover change is less certain. Furthermore, most seasonal climate responses to land cover change have been simulated with atmospheric general circulation models without interactive ocean models 

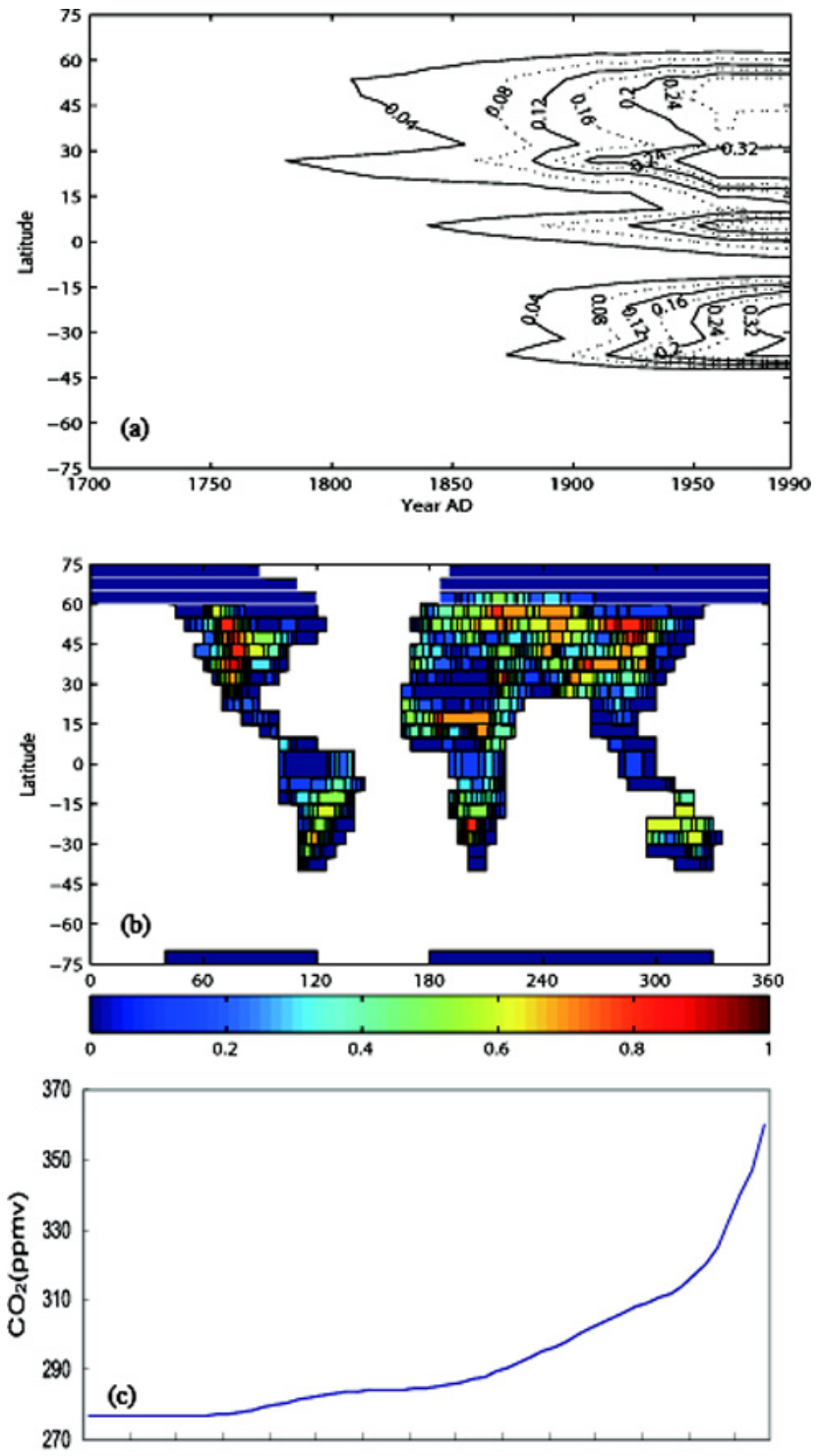

170017201740176017801800182018401860188019001920194019601980 Year AD

Fig. 1. Dynamics of climate forcings used in the simulation. (a) Zonally averaged changes in the cropland and pasture fraction from year 1700; (b) cropland and pasture map in year 1990; (c) $\mathrm{CO}_{2}$ concentration in the atmosphere.

(Brovkin et al., 2004). However, the climate changes induced by land cover changes are affected by feedbacks with sea surface temperature and sea ice, even thermohaline circulation of the ocean. So further studies on historical climate changes due to deforestation are still necessary. In addition, Myhre and Myhre (2003) indicate that model results of the effect of land cover change are highly sensitive to surface albedo values. Nevertheless, the large spread of temperature results from previous studies of land cover change highlights the need for further study on climate sensitivity based on different surface albedos.
In order to allow long model integrations and simulate the response with interactive components in Earth system, an Earth system model of intermediate complexity (EMIC), MPM-2 (Wang and Mysak, 2000), is used to study biogeophysical effects of historical land cover changes on climate and their seasonal effects based on different grassland albedo. EMICs give a complete explanation of the Earth system, which include almost all components. Although they simplify the courses and details using parameterization moderately, they embody the feedbacks and interactions among the components in climate system. So EMICs can simulate the climate change on a large timescale. EMICs are simplified but geographically explicit models capable of simulating all the main processes discussed above. Computational efficiency of these models allows for many sensitivity experiments and the investigation of the influence of uncertainty in climatic forcings and process parameterizations on model results (Forest et al., 2002). In addition, an updated highresolution historical land cover dataset of Klein Goldewijk (2010, 2011, hereafter the HYDE 3.1 dataset) for the last three centuries is used to simulate the climate response to land cover change.

In this paper, MPM-2 is used to investigate the biogeophysical effects of historical land cover change on the earth during the last three centuries based on different grassland albedos, and particularly to assess the response of the climate system to the land cover change seasonally.

\section{Model description and experimental design}

In this study, the McGill Paleoclimate Model-2 (MPM-2) (Wang and Mysak, 2000; Fanning and Weaver, 1996), an Earth system model of intermediate complexity, is employed. As a global climate model, the MPM-2 consists of an energy and moisture balance atmosphere model, a multi-basin zonally averaged dynamic ocean model, a dynamic ice sheet model, a zero-layer thermodynamic-dynamic sea-ice model and a land biosphere model. The north-south resolution is $5^{\circ}$, except across the equator where it is $10^{\circ}$. MPM- 2 has been downscaled to $5 \times 5^{\circ}$ in or over North America and Eurasia. The atmospheric module of MPM-2 is represented by a relatively simple 2-D energy and moisture balance model (EMBM) (Forest et al., 2002), which has a new parameterized solar energy disposition scheme (Wang et al., 2004). The ocean module is a classic zonally averaged dynamic model based on vorticity conservation, which has nine vertical layers and a flat bottom (Wright and Stocker, 1991). The MPM2 employs a simple zero-layer thermodynamic-dynamic seaice model without snow, in which the ice concentration is predicted using the method of Hibler III (1979). In the land surface model, the surface temperature is predicted using the energy balance equation, while the hydrological cycle is simulated using the classic bucket model (Manabe, 1969). The ice sheet model in the MPM-2 is the vertically integrated 
Table 1. Simulation acronyms.

\begin{tabular}{llcc}
\hline Experiment & Simulation & Land cover forcing & $\mathrm{CO}_{2}$ forcing \\
\hline ED & Historical deforestation (land cover changes) & $\mathrm{Yes}^{\mathrm{a}}$ & $\mathrm{No}$ \\
EC & Historical $\mathrm{CO}_{2}$ changes & $\mathrm{No}$ & Yes $^{\mathrm{b}}$ \\
EDC & Historical deforestation and $\mathrm{CO}_{2}$ changes & Yes & Yes \\
\hline
\end{tabular}

a The land cover changes with HYDE 3.1 data for $1700-1990$ are used in simulations. ${ }^{\mathrm{b}}$ For years $1700-1990, \mathrm{CO}_{2}$ is prescribed to the Law Dome, D47, D57 data and Mauna Loa observations (Fig. 1c).

dynamic part of the 2-D ice sheet model of Marshall and Clarke (1997), in which the ice sheet thickness is predicted by an ice mass conservation equation, the ice flow velocity is diagnosed from the ice height, and the bedrock depression is predicted from an isostatic adjustment mode. The MPM2 was also interactively coupled to the dynamical vegetation model of VECODE. This model is based on a continuous bioclimatic classification which provides the relative cover of trees, grasses and potential deserts for each continent and latitude (Brovkin et al., 1997). MPM-2 has successfully simulated changes in the thermohaline circulation state (Wang et al., 2002) and the last glacial inception (z. Wang et al., 2005). Furthermore, MPM-2 has also well simulated the climate changes on a thousand-year scale since the Holocene, such as temperature, precipitation and vegetation distribution (Y. Wang et al., 2005).

To assess the effects of land cover change on climate, HYDE 3.1 of Klein Goldewijk $(2010,2011)$ is used in this study. HYDE 3.1 is an updated and internally consistent combination of historical population estimates and also the implementation of improved allocation algorithms with timedependent weighting maps for cropland and grassland. This dataset includes both historical cropland and pasture on a $5^{\prime} \times 5^{\prime}$ resolution. The HYDE 3.1 data are aggregated to the spatial resolution of the model. The dynamics of zonally averaged changes in the cropland and pasture fraction is shown in Fig. 1a. The middle-northern latitudes experienced rapid cropland and pasture expansion after the year 1900 . The cropland and pasture fraction in year 1990 are shown in Fig. 1b.

Three group transient simulations were performed from 1700 to 1990 (Table 1). In the ED simulation, the land cover was changed in accordance with the land cover scenario, while atmospheric $\mathrm{CO}_{2}$ remained fixed at a concentration of 280 ppmv. In the EC simulation, atmospheric $\mathrm{CO}_{2}$ was changed while land cover forcing was not involved. In EDC simulation, both land cover and $\mathrm{CO}_{2}$ were changed. The trend of $\mathrm{CO}_{2}$ in simulations $\mathrm{EC}$ and EDC for the period 1700-1990 is taken from Law Dome, D47, D57 and Mauna Loa (Etheridge et al., 1998; Stauffer et al., 2002; Keeling and Whorf, 2005), and is shown in Fig. 1c. Last, all simulations are repeated three times with the grassland albedo values of $0.16,0.18$ and 0.20 . Those albedo values are chosen to represent the extreme of grassland albedos represented in the literature (Myhre and Myhre, 2003). In all simulations, initial conditions are taken from pre-industrial equilibrium simulations using present-day orbital forcing and insolation, absence of volcanic eruptions. In order to obtain the same initial conditions, we integrate our simulations from year 1700 to 1990 after a spin-up time of 5300 years to equilibrium. The last 30 years' results of the simulations are averaged to analyze the zonal temperature and albedo change. The final experiments are listed in Table 1.

\section{Results}

All experiments resulted in a global cooling due to land cover changes in ED (Table 2). These changes were forced primarily by increases in surface albedo, which resulted in a negative radiative forcing. Globally averaged temperature changes range from -0.07 to $-0.14^{\circ} \mathrm{C}$, depending on the surface grassland albedo configurations.

As in Matthews et al. (2003), the model is found to be very sensitive to specified surface albedo values. If grassland albedos are increased to 0.20 from the value of 0.18 , the global cooling is increased from 0.09 to $0.14{ }^{\circ} \mathrm{C}$. If grassland albedos are decreased to 0.16 , the global cooling is decreased to $0.07^{\circ} \mathrm{C}$. It is likely that differences in how land cover change effects are affected by surface albedo configuration explains in large part the differences that are shown in simulations of land cover change, which is in line with Myhre and Myhre (2003). The interpretation of land cover change data can also account for discrepancy in model results. Matthews et al. (2004), for example, simulated a cooling over the last three centuries in the range of -0.06 to $-0.22^{\circ} \mathrm{C}$. It is likely that the difference in the model application of the dataset and the reasonable surface albedo configuration explain the minute difference between the results reported here and those of Matthews et al. (2004).

In the above simulations, the spread between the sum of global temperature changes in ED and EC simulations and the global temperature changes in the EDC simulation ranges from 0.04 to $0.06^{\circ} \mathrm{C}$ (see Table 2). For example, with the grassland albedo value of $0.16 \mathrm{EDC}=0.47^{\circ} \mathrm{C}$, while $\mathrm{EC}+\mathrm{ED}=0.52^{\circ} \mathrm{C}$ (Table 2). This indicates a nonlinear additivity of model forcings at the global scale. The difference mostly results from discontinuity presented in the sea ice changes in the Southern Hemisphere (SH) (Petoukhov et al., 
Table 2. Changes in annual mean global and $\mathrm{NH}$ temperature $\left({ }^{\circ} \mathrm{C}\right)$.

\begin{tabular}{lcccc}
\hline Experiment & $T_{\mathrm{ED}}$ & $T_{\mathrm{EC}}$ & $T_{\mathrm{EDC}}$ & $\left(T_{\mathrm{ED}}+T_{\mathrm{EC}}\right)-T_{\mathrm{EDC}}$ \\
\hline Alb-0.16 & $-0.07 /-0.12^{\mathrm{b}}$ & $0.59 / 0.64$ & $0.47 / 0.47$ & $0.05 / 0.05$ \\
Alb-0.18 & $-0.09 /-0.15$ & $0.6 / 0.62$ & $0.45 / 0.43$ & $0.06 / 0.04$ \\
Alb-0.20 & $-0.14 /-0.22$ & $0.53 / 0.61$ & $0.35 / 0.37$ & $0.04 / 0.02$ \\
\hline
\end{tabular}

a The HYDE dataset with grassland albedo set to $0.16{ }^{\mathrm{b}}$ Global/Northern Hemisphere.

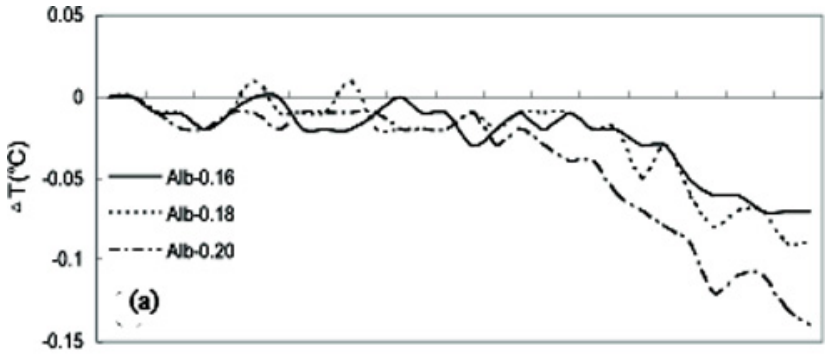

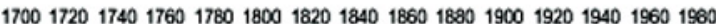

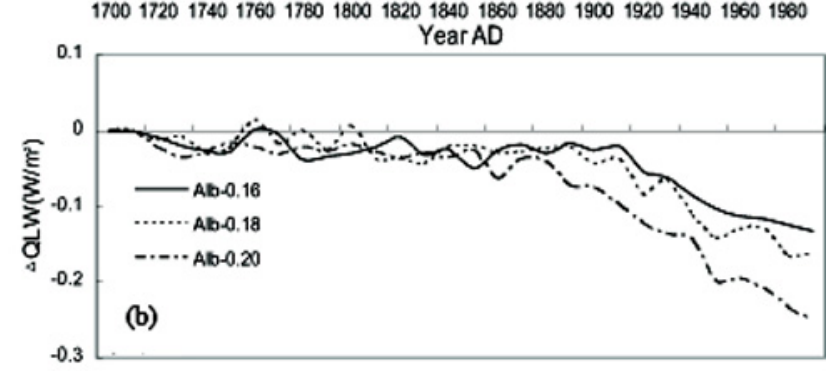

170017201740176017801800182018401860188019001920194019601980

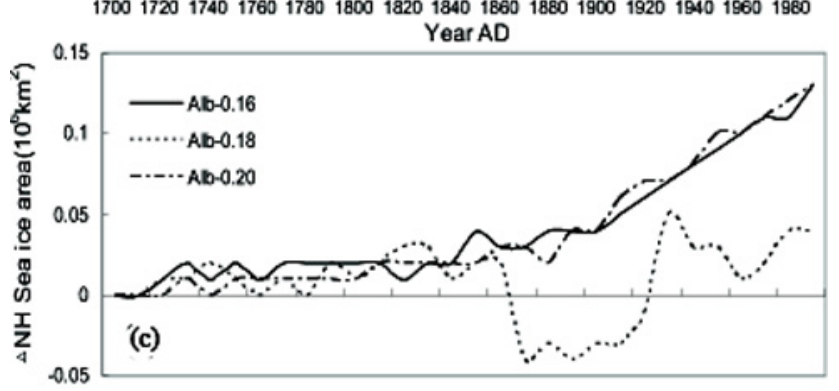

170017201740176017801800182018401860188019001920194019601980

Year AD

Fig. 2. Changes in (a) annual mean global temperature $\left({ }^{\circ} \mathrm{C}\right)$; (b) outgoing long-wave radiation (QLW) $\left(\mathrm{W} \mathrm{m}^{-2}\right)$; (c) sea ice area for $\mathrm{NH}\left(10^{6} \mathrm{~km}^{2}\right)$, for simulation ED.

2005). Also their mutual offsetting of the two effects could be responsible for this response as well.

\subsection{Transient response of the annual mean global tem- perature, outgoing long-wave radiation and sea ice area for NH in the ED simulation}

In response to the historical land cover changes, the dataset with different grassland albedos simulate a decline in the annual mean global temperature. Among the simulation, Alb0.20 shows the strongest cooling. However, the general cool- ing tendency for these simulations is clearly seen in Fig. 2. Before the year 1900, changes in global temperature are rather small (less than $-0.01^{\circ} \mathrm{C}$ ) and they accelerate after the year 1900, reaching a maximum in year 1990. The trend is accounted for the temporal and spatial dynamics of the land cover changes (Fig. 1a). Before the year 1900, the magnitude of decrease in temperature is the same among different grassland albedos on the whole, while the decrease with grassland albedo of 0.20 is obviously larger than others after the year 1900. This shows that the negative effect of larger grassland albedo on climate is more prominent when the temperature decrease is larger. The effects of different grassland albedos on climate are nonlinear. In response to the land cover changes, outgoing long-wave radiation (OLWR) decreases by up to $0.25 \mathrm{~W} \mathrm{~m}^{-2}$ in the annual mean with the grassland albedo value of 0.20 (Fig. 2b). The decrease in outgoing long-wave radiation is less than $0.1 \mathrm{~W} \mathrm{~m}^{-2}$ before the year 1900 and then decrease wavily. The general trend of the outgoing long-wave radiation change is in line with the global temperature change. The decrease is largely explained by the surface air temperature reduction.

Due to the greater number of landmasses in the Northern Hemisphere $(\mathrm{NH})$ that respond to external climatic forcings (e.g., changes in insolation or $\mathrm{CO}_{2}$ concentration) more rapidly than does the thermally inert ocean, the response of the sea ice area for $\mathrm{NH}$ is assessed. The $\mathrm{NH}$ sea ice area increases slowly with the temperature decrease before the year 1860, and increases quickly after the year 1870 with grassland albedo of 0.16 and 0.20 (Fig. 2c). There is a rapid reduction from year 1860 and a rise from the year 1920 in $\mathrm{NH}$ sea ice area with grassland albedo of 0.18 , which results from the temperature change. As a result of reduction in temperature, the sea ice cover expands, which leads to the decrease in absorbing short-wave radiation, and could affect sea surface temperature and sea ice area, even the thermohaline circulation through nonlinear interactions in the climate system. The results suggest that the potential influence of land cover changes could be very large owing to the nonlinear response of temperature to land cover change, which should be paid more attention to.

A classic Student's $t$ test is applied to comparable $30 \mathrm{yr}$ climatologies at each grid cell, while all grid cells over land except regions over equator and low latitudes of $\mathrm{SH}$ are statistically significant at the 0.05 confidence level in the annual temperature change with grassland albedo of 0.16 . When 

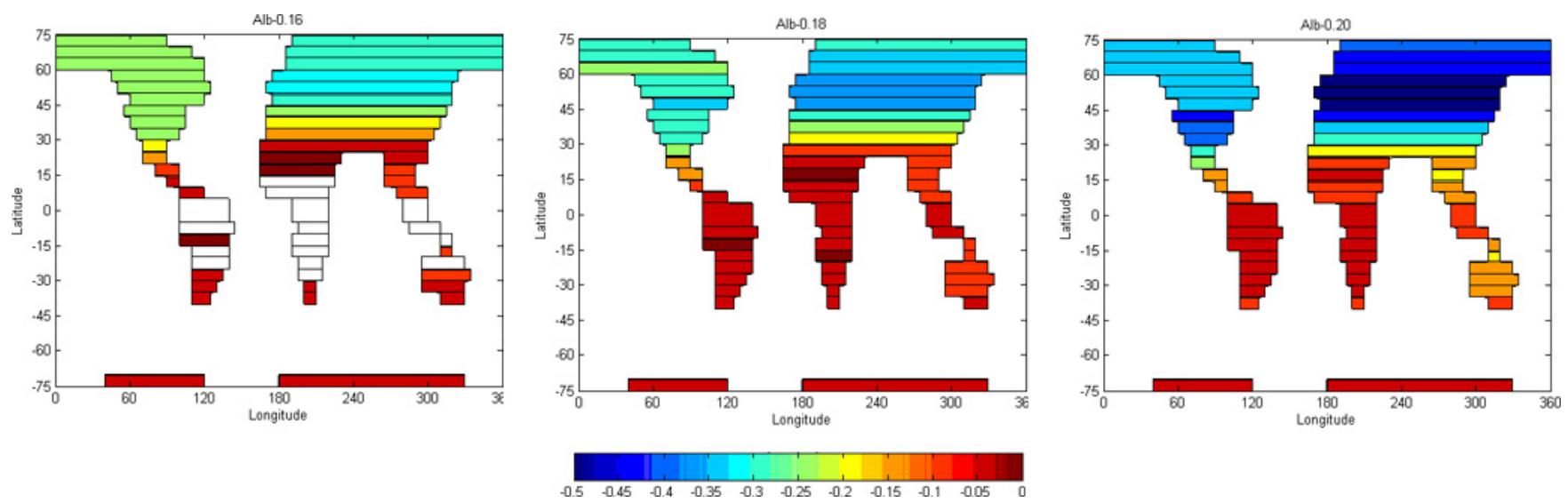

Fig. 3. Averaged changes in surface air temperature $\left({ }^{\circ}\right)$ for different surface albedos. (a) Grassland albedo of 0.16 ; (b) grassland albedo of 0.18; (c) grassland albedo of 0.20 . Only areas where changes are significant at a $95 \%$ confidence using the Student's $t$ test are shown.

changes are statistically significant at this level, it means the model-simulated changes are more than twice as large as the model's internal variation (Zhang et al., 2001). The statistically significant change over land accounts for the parameterized advection in MPM-2 which leads to universal climate changes. Even the heat transportation of the ocean is heavily dependent on parameterization. This statistically significant change over land is in line with some studies. Feddema et al. (2005) found a statistically significant cooling over most of the planet in the traditional difference of the mean test. The wide-spread climate change in this paper is different from some studies' large local climate change, which results form the small influence of advection (Pitman et al., 2009). There are marked differences in the magnitude of global cooling in response to land cover changes based on different grassland albedos (Fig. 3). The region shows a decrease in annually averaged temperature with the largest change in the middle latitudes over Eurasia.

\subsection{Effects of historical land cover changes on zonal and seasonal temperature and albedo}

Due to the larger landmass in NH, we highlight the effects of deforestation on zonal and seasonal temperature and albedo in NH. The effect of land cover changes on zonally averaged temperature is shown on Fig. 4. The simulation shows a pronounced maximum cooling of about $0.45^{\circ} \mathrm{C}$ in the annual average around $50^{\circ} \mathrm{N}$ with grassland albedo of 0.20 . The cooling trend is broadly similar with different grassland albedos in NH. The temperature reduction to the north of the deforested areas is due to changes in SSTs (sea surface temperatures) and sea ice cover. The response in the low latitudes and SH is much less prominent. This is due to the fewer number of landmasses in the SH as compared to the $\mathrm{NH}$, and the geographical distribution of the forcing. Similar grassland albedo value differences in the $\mathrm{NH}$ are seen for seasonal temperatures (see Fig. 4b-d). The cooling during spring (MAM, Fig. 4b) is distinct but not as significant as during JJA (Fig. 4c). The simulation results show a maximum response of $0.57{ }^{\circ} \mathrm{C}$ with grassland albedo of 0.20 around $50^{\circ} \mathrm{N}$. During the northern summer (JJA, Fig. 4c), the response to land cover changes is most substantial, with maximum cooling reaching approximately $0.6^{\circ} \mathrm{C}$ with grassland albedo of 0.20 around $50^{\circ} \mathrm{N}$. The winter shows a maximum response of about $0.3{ }^{\circ} \mathrm{C}$ with grassland albedo of 0.20 around $40^{\circ} \mathrm{N}$ and $50^{\circ} \mathrm{N}$ (Fig. 4d). A cooling in the high northern latitudes is mostly explained by an increase in sea ice in the northern ocean.

The prominent cooling in the northern middle latitudes largely accounts for changes in land surface albedo (Fig. 5). Annually averaged increase in albedo is more than 0.02 over $50^{\circ} \mathrm{N}$ (Fig. 5a). The increase in the surface albedo with grassland albedo of 0.20 is obviously greater in most regions. The strong increase in the albedo is resulted from the strong deforestation in this region (Fig. 1a). During spring, the maximum increase in surface albedo is very large and reaches nearly 0.08 with grassland albedo of 0.20 over $50^{\circ} \mathrm{N}$ (Fig. 5b), which suggests that this surface albedo difference was the main driver of the significant temperature change (Fig. 4b) in these regions during this part of the year. The albedo changes become small during the summer season since the radiative effect due to snow-masking of forest is absent (Fig. 5c). Historical deforestation results in a land albedo increase of less than 0.02 in most regions. This suggests that the surface albedo change is not the main cause of the marked temperature change (Fig. 4c) in this season. During December-February the maximum increase in surface albedo is more than 0.02 , which is larger than that of summer and smaller than that of spring in the northern middle latitudes (Fig. 5d). This albedo change has effects on temperature within limits because of the small solar radiation during winter (Fig. 4d).

Deforestation causes change in absorbed short-wave radiation at the land surface due to the imposed increase in surface 

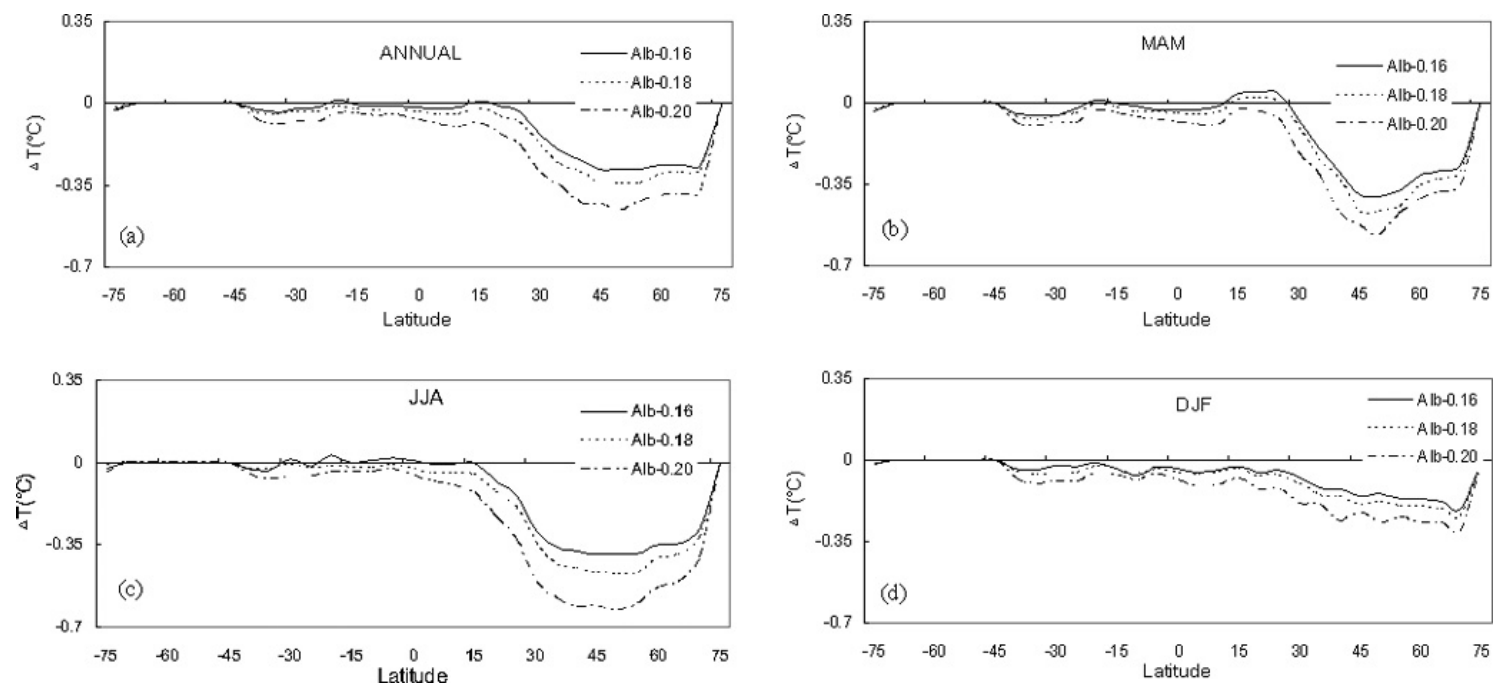

Fig. 4. Zonally averaged changes in temperature $\left(^{\circ}\right)$ for different seasons, (a) annual; (b) MAM (March-May); (c) JJA (June-August); (d) DJF (December-February), for simulation ED.
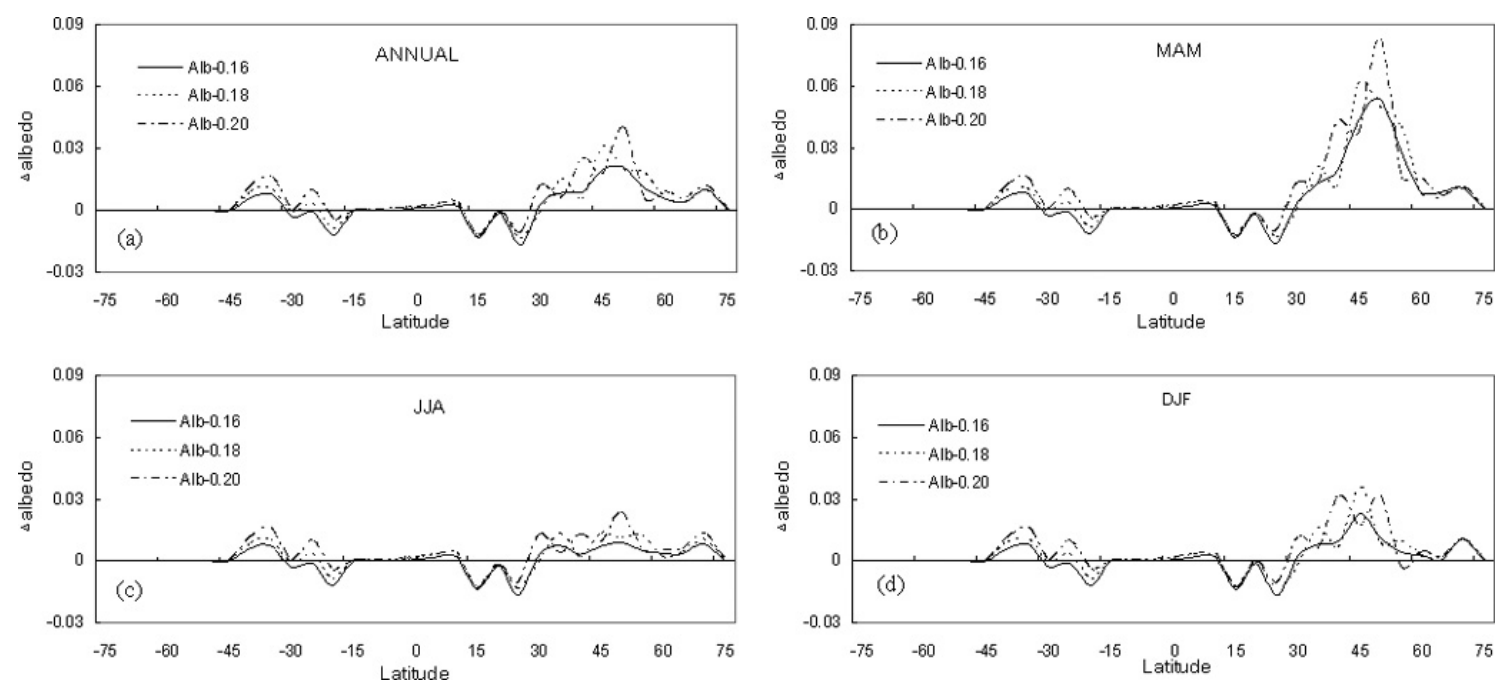

Fig. 5. Zonally averaged changes in surface albedo for different seasons, (a) annual; (b) MAM (March-May); (c) JJA (June-August); (d) DJF (December-February), for simulation ED.

albedo. Deforestation also alters the surface radiative energy partition between latent and sensible heat fluxes and thus affects the surface moisture and thermal properties. Therefore, analyzing the surface and atmospheric energy budgets will potentially give a more comprehensive understanding of the overall biogeophysical effect of land cover change. The disposition of energy into sensible and latent heat fluxes is governed in part by net radiation, but also by the availability of water to drive latent heat fluxes. Latent heat fluxes are also dependent on the vegetation type and its efficiency with respect to transpiration (Bonan, 1999). In the temperate latitudes, land cover conversion causes a decrease in the sensible heat flux and latent heat flux (Fig. 6). There is a significant reduction in simulation Alb-0.20. The maximum de- creases in sensible heat flux is $0.11 \mathrm{~W} \mathrm{~m}^{-2}$ over $50^{\circ} \mathrm{N}$ and latent heat flux is maximally reduced by $0.13 \mathrm{~W} \mathrm{~m}^{-2}$ over $40^{\circ} \mathrm{N}$, which are to a large extent due to the decrease in net short-wave radiation associated with the albedo increase. These changes are smaller than those in some previous studies. Feddema et al. (2005), using a GCM, find that latent heat flux decreases by $0.60 \mathrm{~W} \mathrm{~m}^{-2}$ and sensible heat flux is reduced by $0.05 \mathrm{~W} \mathrm{~m}^{-2}$ in response to historical human land cover change. The spread can be accounted for by the different model and parameterizations. 

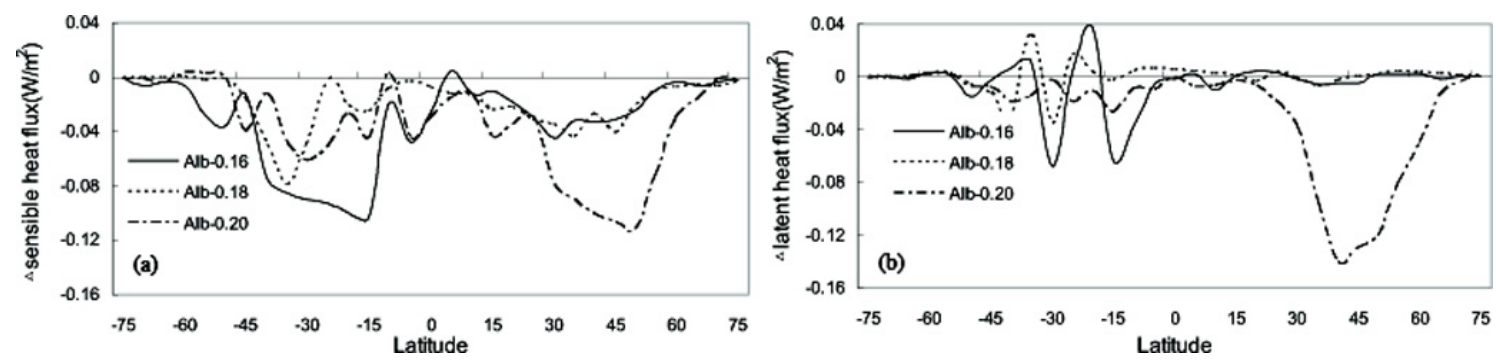

Fig. 6. Zonally annual averaged changes in (a) sensible heat flux; (b) latent heat flux.
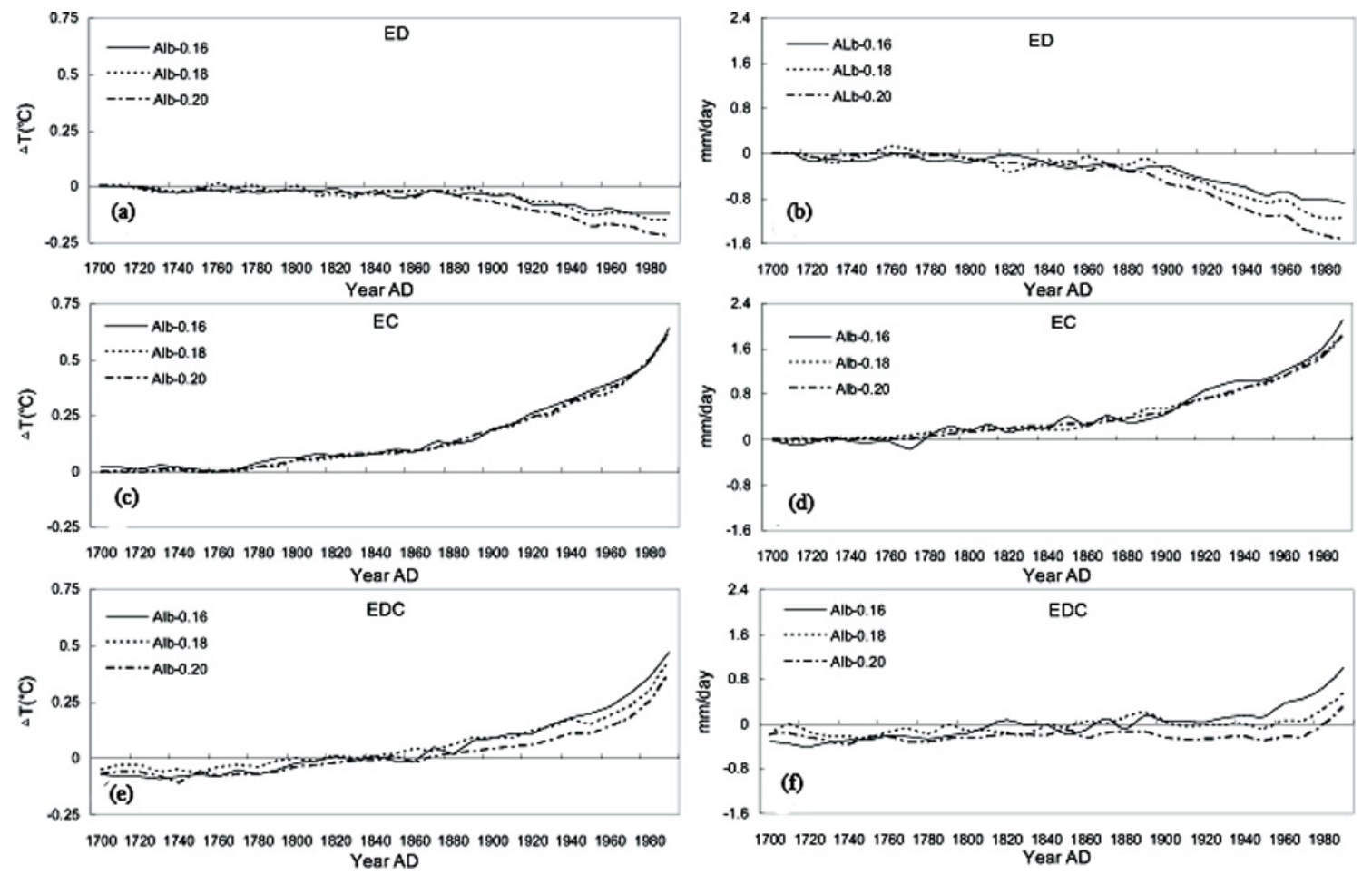

Fig. 7. Simulated climatic changes in the ED (a), (b), EC (c), (d) and EDC (e), (f) simulations. (a), (c) and (e) Changes in annual mean temperature for $\mathrm{NH}\left(^{\circ}\right)$; (b), (d) and (f) changes in annual mean integrated precipitation over $45-75^{\circ} \mathrm{N}\left(\mathrm{mm} \mathrm{day}^{-1}\right)$.

\subsection{Effects of land cover and $\mathrm{CO}_{2}$ forcings on $\mathrm{NH}$ tem- perature and integrated precipitation over $45-75^{\circ} \mathrm{N}$}

To compare the effects of historical land cover change with the effects of $\mathrm{CO}_{2}$ increases, we analyze results from the land cover change representation with different grassland albedo values. Due to the larger landmass in the $\mathrm{NH}$, the most pronounced land cover change in this are is over 45 $75^{\circ} \mathrm{N}$ (Fig. 1a); the annual mean temperature for $\mathrm{NH}$ and the integrated precipitation over $45-75^{\circ} \mathrm{N}$ are estimated.

In response to land cover changes only (ED), global temperature decreases by $0.07-0.14{ }^{\circ} \mathrm{C}$ (Table 2 ); simulated transient changes in annual mean temperature for NH (Fig. 7a) qualitatively follow those for global temperature while the quantitative response of the global (Fig. 2a) is smaller. Before the year 1900 decreases in $\mathrm{NH}$ temperature are rather small (less than $-0.1^{\circ} \mathrm{C}$ ), yet they accelerate after the year 1900 and reach a maximum value of $0.22^{\circ} \mathrm{C}$ in 1990 with the grassland albedo of 0.20 . These trends are explained by the temporal and spatial dynamics of the land cover changes for NH. All simulations show a decrease in integrated precipitation over $45-75^{\circ} \mathrm{N}$ (Fig. 7b) in response to reduced tree cover; the simulation with the grassland albedo of 0.20 presents the strongest reduction in precipitation over 45$75^{\circ} \mathrm{N}$ during the last few decades. The decrease accelerates after 1900 and reaches a maximum in the 1990s, which is in accord with the change of temperature.

In response to $\mathrm{CO}_{2}$ forcing only (EC), all grassland albedos demonstrate a similar trend of $\mathrm{NH}$ temperature increase. The spread of the increase among the different grassland albedos is small (Fig. 7c). In the EC simulation, the global hydrological cycle is enhanced in all grassland albedos and 
precipitation over $45-75^{\circ} \mathrm{N}$ with grassland albedo of 0.16 shows a stronger response than that with the other grassland albedos (Fig. 7d).

In response to the combination of land cover and $\mathrm{CO}_{2}$ forcings in simulation EDC, all simulations show a cooling before the year 1800 and a warming after the year 1900 (Fig. 7e). The simulations reveal a minimum warming in the 1910 s associated with the onset of $\mathrm{CO}_{2}$ forcing, which begins to offset the deforestation forcing. In the 20th century, the $\mathrm{CO}_{2}$-induced warming dominates over the cooling associated with land cover changes. The same qualitative pattern also holds for precipitation over $45-75^{\circ} \mathrm{N}$ (Fig. 7f).

\section{Discussion}

In the ED simulation, the MPM-2 simulates a cooling of $0.07-0.14{ }^{\circ} \mathrm{C}$ due to land cover biogeophysical effects at the global scale, which is within the range of cooling revealed by previous studies (Brovkin et al., 2004; Betts, 2001; Bertrand et al., 2002; Matthews et al., 2004). The spread among the results in this study and previous estimates are accounted for different model parameterizations and the reasonable surface albedo configuration. In addition, radiative forcing is a tool that in a simple way can be used to compare different biogeophysical cooling mechanisms. In this paper, a decrease in radiative forcing in response to historical land cover changes amounts to 0.12 to $0.32 \mathrm{~W} \mathrm{~m}^{-2}$ for the periods 1700-1990. This estimate is well within the range of -0.01 to $-0.5 \mathrm{~W} \mathrm{~m}^{-2}$, which is estimated by previous simulations (Houghton et al., 2001; Myhre and Myhre, 2003; Matthews et al., 2004; Goosse et al., 2005; Sitch et al., 2005; Pongratz et al., 2009). The spreads among the different estimates may be caused by different parameterization of the vegetation influence on land surface albedo and approaches for radiative forcings estimation (Brovkin et al., 2006).

A global cooling is simulated due to land cover biogeophysical effects during the last three centuries, while the cooling varies with seasons. The effects of land cover changes is most pronounced around $50^{\circ} \mathrm{N}$, with maximum cooling reaching approximately $0.6^{\circ} \mathrm{C}$ during summer and comparing with that during spring (Fig. 4), which is in line with some previous simulations. Bonan (1997), using the modified CCM2 model with prescribed SST, revealed a significant summer cooling of $2{ }^{\circ} \mathrm{C}$ resulted from land cover changes. The mid-latitude cooling trends are strongly associated with the summer season due to very significant reductions in net radiation in the mid-latitudes (Feddema et al., 2005). The imposed land cover change led to statistically significant cooling in the Northern Hemisphere summer near-surface temperature over regions of land cover change (Pitman et al., 2009). Bounoua et al. (2002), in deforestation experiments with a GCM coupled to a SiB2, showed that deforestation leads to a cooling of $0.7^{\circ} \mathrm{C}$ in summer. However, the maximum summer cooling is in contradiction with re- sults of some AGCM simulations, which show an increase in summer air temperature or a smaller decrease than in winter and spring (Bonan et al., 1992; Betts, 2001). One reason can be that most of the AGCMs were conducted with prescribed SSTs, which modified the global response considerably. Prescribed SSTs neglect the water vapor feedback over the sea surface and may reverse the sign of zonally averaged temperature changes (Ganopolski et al., 2001). In addition, Brovkin et al. (1999) found that, within numerical experiments using CLIMBER-2, a maximum cooling of $1.5^{\circ} \mathrm{C}$ occurred in the northern temperate and high latitudes during spring owing to the albedo effect, which differs from the results in this paper. The spread is largely caused by the CLIMBER-2 without any flux adjustment between the atmospheric and oceanic modules, which influences the feedbacks among EMICs components and affects the global response considerably, particularly those components involving sea ice and water vapor. However, the atmosphere module here is represented by a simple EMBM in the absence of detailed descriptions about atmospheric circulations and cloud dynamics, so there are still some limitations about rainfall in our simulations. Furthermore, the simulation in our study does not involve cloud feedback, which also affects the climate response. Most AGCMs simulate an increase in cloud cover, which would reduce forcing due to deforestation by decreasing the effect of changes in surface albedo on net radiative fluxes at the top of the atmosphere in response to surface cooling. Due to the absence of the cloud feedback, the climate response is likely to be underestimated in the simulation.

\section{Conclusion}

Human-induced land cover change has potentially important effects on regional and global climate change. As do most historical land cover change studies, this study shows that land cover change during the last three centuries has led to a global cooling. MPM-2 reveals a large spread in biogeophysical cooling effects due to grassland changes, and the results are within a range of $0.07-0.14{ }^{\circ} \mathrm{C}$ at the global scale, forced by historical land cover changes. Larger grassland albedo leads to more prominent cooling effects. The effect of land cover change is most pronounced around $50^{\circ} \mathrm{N}$, with a maximum cooling of $0.45^{\circ} \mathrm{C}$ on global scale due to its obvious replacement of forest with grassland albedo of 0.20 . Much larger contrasts are found on the seasonal scale, while these changes are largely offsetting on the yearly scale. The maximum cooling reaches approximately $0.6^{\circ} \mathrm{C}$ around $50^{\circ} \mathrm{N}$ during summer, while the cooling reaches only $0.57^{\circ} \mathrm{C}$ during northern spring owing to the larger increase in land surface albedo of 0.08 with grassland albedo of 0.20 . These results suggest that selected surface albedo is important in assessing climate change and indicate that land cover changes 
need to be included in regional and seasonal climate change simulations.

Acknowledgements. Special thanks to Shi Zhengguo for his assistance in running the experiments, and two anonymous reviewers for their useful comments on the manuscript. This research was supported by Major Project of Chinese National Programs for Fundamental Research and Development (973 Program) (Grant No. 2010CB950903) and NUAA Foundation (Grant No. 1007909369 and 1007-XNA12078).

Topical Editor P. M. Ruti thanks two anonymous referees for their help in evaluating this paper.

\section{References}

Bertrand, C., Loutre, M. F., Crucifix, M., and Berger, A.: Climate of the last millennium: a sensitivity study, Tellus A, 54, 221-244, 2002.

Betts, R. A.: Biogeophysical impacts of land use on presentday climate: near-surface temperature and radiative forcing, Atmos. Sci. Lett., 2, 39-51, 2001.

Bonan, G. B.: Effects of land use on the climate of the United States, Climatic Change, 37, 449-486, 1997.

Bonan, G. B.: Frost followed the plow: impacts of deforestation on the climate of the United States, Ecol. Appl., 9, 1305-1315, 1999.

Bonan, G. B., Pollard, D., and Thompson, S. L.: Effects of boreal forest vegetation on global climate, Nature, 359, 716-718, 1992.

Bounoua, L., DeFries, R., Collatz, G. J., Sellers, P., and Khan, H.: Effects of land cover conversion on surface climate, Clim. Change, 52, 29-64, 2002.

Brovkin, V., Ganopolski, A., and Svirezhev, Y.: A continuous climate-vegetation classification for use in climate-biosphere studies, Ecol. Modelling, 101, 251-261, 1997.

Brovkin, V., Ganopolski, A., Claussen, M., Kubatzki, C., and Petoukhov, V.: Modelling climate response to historical land cover change, Global Ecology Biogeography, 8, 509-517, 1999.

Brovkin, V., Sitch, S., von Bloh, W., Claussen, M., Bauer, E., and Cramer, W.: Role of land cover changes for atmospheric $\mathrm{CO}_{2}$ increase and climate change during the last 150 years, Global Change Biology, 10, 1253-1266, 2004.

Brovkin, V., Claussen, M., Driesschaert, E., Fichefet, T., Kicklighter, D., Loutre, M. F., Matthews, H. D., Ramankutty, N., Schaeffer, M., and Sokolov, A.: Biogeophysical effects of historical land cover changes simulated by six Earth system models of Intermediate complexity, Clim. Dynam., 26, 587-600, 2006.

Chase, T. N., Pielke, R. A., Kittel, T. G. F., Nemani, R. R., and Running, S. W.: Simulated impacts of historical land cover changes on global climate in northern winter, Clim. Dynam., 16, 93-105, 2000 .

Etheridge, D. M., Steele, L. P., Langenfelds, R. L., Francey, R. J., Barnola, J. M., and Morgan, V. I.: Historical $\mathrm{CO}_{2}$ records from the Law Dome DE08, DE08-2, and DSS ice cores In Trends: A Compendium of Data on Global Change. Tenn: Carbon Dioxide Information Analysis Center Oak Ridge National Laboratory, US Department of Energy Oak Ridge, 1998.

Fanning, A. F. and Weaver, A. J.: An atmospheric energy-moisture balance model: Climatology, interpentadal climate change, and coupling to an ocean general circulation model, J. Geophys Res., 101, 15111-15128, 1996.

Feddema, J., Oleson, K., Bonan, G., Mearns, L., Washington, W., Meehl, G., and Nychka, D.: A comparison of a GCM response to historical anthropogenic land cover change and model sensitivity to uncertainty in present-day land cover representations, Clim. Dynam., 25, 581-609, 2005.

Forest, C. E., Stone, P. H., Sokolov, A. P., Allen, M. R., and Webster, M. D.: Quantifying uncertainties in climate system properties with the use of recent climate observations, Science, 295, 113-117, 2002.

Ganopolski, A., Petoukhov, V., Rahmstorf, S., Brovkin, V., Claussen, M., Eliseev, A., and Kubatzki, C.: CLIMBER- 2: a climate system model of intermediate complexity. Part II: validation and sensitivity tests, Clim. Dynam., 17, 735-751, 2001.

Goosse, H., Renssen, H., Timmermann, A., and Bradley, R. S.: Internal and forced climate variability during the last millennium: a model-data comparison using ensemble simulations, Quat. Sci. Rev., 24, 1345-1360, 2005.

Govindasamy, B., Duffy, P. B., and Caldeira, K.: Land use changes and Northern Hemisphere cooling, Geophys. Res. Lett., 28, 291294, 2001.

Hibler III, W. D.: A dynamic thermodynamic sea ice model. J. Phys. Oceanogr., 9, 815-846, 1979.

Houghton, J. T., Ding, Y., Griggs, D. J., Noguer, M., van der Linden, P. J., Dai, X., Maskell, K., and Johnson, C. A. (Eds.): Climate Change 2001: The Scientific Basis, Cambridge University Press, 881 pp., 2001.

Keeling, C. D. and Whorf, T. P.: Atmospheric $\mathrm{CO}_{2}$ records from sites in the SIO air sampling network. In Trends: A Compendium of Data on Global Change, Tenn: Carbon Dioxide Information Analysis Center Oak Ridge National Laboratory US Department of Energy Oak Ridge, 2005.

Klein Goldewijk, K., Beusen, A., and Janssen, P.: Long term dynamic modeling of global population and built-up area in a spatially explicit way, HYDE 3.1, The Holocene, 20, 565-573, 2010.

Klein Goldewijk, K., Beusen, A., de Vos, M., and van Drecht, G.: The HYDE 3.1 spatially explicit database of human induced land use change over the past 12000 years, Global Ecology Biogeography., 20, 73-86, 2011.

Manabe, S.: Climate and the ocean circulation. I: The atmospheric circulation and the hydrology of the earth surface, Mon.Weather Rev., 97, 739-774, 1969.

Marshall, S. J. and Clarke, G. K. C.: A continuum mixture model of ice stream thermomechanics in the Laurentide Ice Sheet, 1. Theory, J. Geophys. Res., 102, 20599-20613, 1997.

Matthews, H. D.,Weaver, A. J., Eby, M., and Meissner, K. J.: Radiative forcing of climate by historical land cover change, Geophys. Res. Lett., 30, 1055, doi:10.1029/2002GL016098, 2003.

Matthews, H. D., Weaver, A. J., Meissner, K. J., Gillett, N. P., and Eby, M.: Natural and anthropogenic climate change: Incorporating historical land cover change, vegetation dynamics and the global carbon cycle, Clim. Dynam., 22, 461-479, 2004.

Myhre, G. and Myhre, A.: Uncertainties in radiative forcing due to surface albedo changes caused by land-use changes, J. Climate, 16, 1511-1524, 2003.

Petoukhov, V., Claussen, M., Berger, A., Crucifix, M., Eby, M., Eliseev, A. V., Fichefet, T., Ganopolski, A., Goosse, H., Kamenkovich, I., Mokhov, I. I., Montoya, M., Mysak, L. A., 
Sokolov, A., Stone, P., Wang, Z., and Weaver, A. J.: EMIC Intercomparison Project (EMIP CO2): Comparative analysis of EMIC simulations of climate, and of equilibrium and transient responses to atmospheric $\mathrm{CO}_{2}$ doubling, Clim. Dynam., 25, 363385, doi:10.1007/s00382-005-0042-3,2005.

Pitman, A. J. and Zhao, M.: The relative impact of observed change in land cover and carbon dioxide as simulated by a climate model, Geophys. Res. Lett., 27, 1267-1270, 2000.

Pitman, A. J., de Noblet-Ducoudré, N., Cruz, F. T., Davin, E. L., Bonan, G. B., Brovkin, V., Claussen, M., Delire, C., Ganzeveld, L., Gayler, V., van den Hurk, B. J. J. M., Lawrence, P. J., van der Molen, M. K., Müller, C., Reick, C. H., Seneviratne, S. I., Strengers, B. J., and Voldoire, A.: Uncertainties in climate responses to past land cover change: First results from the LUCID intercomparison study, Geophys. Res. Lett., 36, L14814, doi:10.1029/2009GL039076, 2009.

Pongratz, J., Raddatz, T., Reick, C. H., Esch, M., and Claussen, M.: Radiative forcing from anthropogenic land cover change since A.D. 800, Geophys, Res. Lett., 36, L02709, doi:10.1029/2008GL036394, 2009.

Shi, Z., Yan, X., Yin, C., and Wang, Z.: Effects of historical land cover changes on climate, Chinese Sci. B., 18, 2575-2583, 2007.

Sitch, S., Brovkin, V., von Bloh, W., van Vuuren, D., Eickhout, B., and Ganopolski, A.: Impacts of future land cover changes on atmospheric $\mathrm{CO}_{2}$ and climate, Global Biogeochem. Cycles, 19, GB2013, doi:10.1029/2004GB002311, 2005.
Stauffer, B., Fluckiger, J., Monnin, E., Schwander, J., Barnola, J. M., and Chappellaz, J.: Atmospheric $\mathrm{CO}_{2}, \mathrm{CH}_{4}$ and $\mathrm{N}_{2} \mathrm{O}$ records over the past 60000 years based on the comparison of different polar ice cores, Ann. Glaciol., 35, 202-208, 2002.

Wang, Y., Mysak, L. A., Wang, Z., and Brovkin V.: The greening of the McGill Paleoclimate Model. Part II: Simulation of Holocene millennial-scale natural climate changes, Clim. Dynam., 24, 481-496, 2005.

Wang, Z. and Mysak, L. A.: A simple coupled atmosphere-oceansea ice-land surface model for climate and paleoclimate studies, J. Climate, 13, 1150-1172, 2000.

Wang, Z., Mysak, L. A., and McManus, J. F.: Response of the thermohaline circulation to cold climates, Paleoceanography, 17, 1006, doi:10.1029/2000PA000587, 2002.

Wang, Z., Hu, R. M., Mysak, L. A., Blanchet, J. P., and Feng, J.: A parameterization of solar energy disposition in the climate system, Atmos. Ocean, 42, 113-125, 2004.

Wang, Z., Cochelin, A. B., Mysak, L. A., and Wang, Y.: Simulation of the last glacial inception with the green McGill Paleoclimate Model, Geophys. Res. Lett., 32, L12705, doi:10.1029/2005GL023047, 2005.

Wright, D. G. and Stocker, T. F.: A zonally averaged ocean model for the thermohaline circulation. Part I: Model development and flow dynamics, J. Phys. Oceanogr., 21, 1713-1724, 1991.

Zhang, H., Henderson-sellers, A., and Mcguffie, K.: The compounding effects of tropical deforestation and greenhouse warming on climate, Clim. Change, 49, 309-338, 2001. 